\title{
Isolation and Characterization of Glutaminase-free L-asparaginase Produced by Staphylococcus sp. MGM1
}

\author{
Gholamhossein Ebrahimipour ${ }^{\text {a }}$, Mohammad Yaghoobi Avini ${ }^{\text {a }}$ \\ Mahtab Ghorbanmovahed ${ }^{\mathrm{a}^{*}}$ \\ ${ }^{a}$ Department of Microbiology and Microbial Biotechnology, Faculty of Life Sciences and Biotechnology, Shahid Beheshti University, \\ Tehran, Iran.
}

Received 10 March 2020; Accepted 11 May 2020

\begin{abstract}
L-asparaginase is an important therapeutic enzyme used in combination with other drugs for therapy of Acute Lymphoblastic Leukemia (ALL). L-asparaginase catalyzes the conversion of asparagine to aspartic acid and ammonia. In recent years, this enzyme gained applications in many fields of science such as clinical research, pharmacological, and food industries. This study was aimed at isolation and identification of a strain with the ability to producing extracellular glutaminase free L-asparaginase from soil and determination of enzyme stability. The isolation was done on M9 medium. Biochemical tests and 16S rDNA sequence was used for strain identification. L-asparaginase was partially purified using ammonium sulfate precipitation, dialysis, and DEAE-anion exchange chromatography. The effect of $\mathrm{pH}$ and temperature on enzyme activity was investigated. The isolated bacteria were identified as Staphylococcus sp. The optimum $\mathrm{pH}$ and temperature for maximum L-asparaginase activity were found at 8 and $35{ }^{\circ} \mathrm{C}$. The enzyme purification showed a single band around $115 \mathrm{kDa}$ on SDS-Page. The optimal activity for the enzyme produced by MGM1 was similar to the physiological conditions of the human body, therefore, further studies on this enzyme would be of great value in finding a new efficient asparaginase enzyme.
\end{abstract}

Keywords: Isolation; L-asparaginase; Acute Lymphoblastic Leukemia (ALL); Staphylococcus; Glutaminase-free.

\section{Introduction}

L-asparaginase (L-asparagine amidohydrolase E.C. 3.5.1.1) is an important chemotherapeutic enzyme that hydrolysis L-asparagine to L-aspartate and ammonia. This enzyme has been used for the treatment of certain kinds of cancer like Acute Lymphoblastic Leukemia (ALL) and non-Hodgkin lymphoma [1, 2]. The antitumor action of asparaginase is due to the fact that ALL tumor cells have notability for de-novo synthesis of the nonessential amino acid asparagine because of absence of asparagine synthetase and therefore, require huge amount of asparagine to keep up their rapid malignant growth and mainly depend on the L-asparagine from the circulating plasma pools [3-5]. Supplementation of L-asparaginase results in the continuous depletion of L-asparagine [6]. The nutritional stressinduced by asparaginase due to the reduction of serum asparagine; inhibits DNA, RNA and protein biosynthesis in ALL and other asparagine dependent tumor cells, that causes subsequent apoptosis [5].

However, normal cells remain unaffected due to the presence of asparagine synthetase [1,4]. Another application of L-asparaginase is found in the baking process, where the Millard reaction between sugar and asparagine at temperatures above $180^{\circ} \mathrm{C}$ results in brown color and production of acrylamide which is a carcinogenic by-product [6]. L-asparaginase is an intracellular enzyme and produced by various microorganisms, plants, and animal tissue but

* Corresponding author: mghorbanmovahed@gmail.com

$>$ This is an open access article under the CC-BY license (https://creativecommons.org/licenses/by/4.0/).

(C) Authors retain all copyrights. 
not human [7, 8]. Plants and animal-based enzyme sources produce in sufficient quantities. Microorganisms like bacteria, yeast, fungi, actinomycetes, and algae are very effective producers because they can be cultured easily and the extraction and the purification of L-asparaginase from them are also convenient, facilitating the large scale production [8, 9]. Among the common sources of L-asparaginase are microorganisms such as: Escherichia coli [10], Erwinia carotovora [11], Enterobacter aerogenes [12], Corynebacterium glutamicum [13], Pseudomonas aeruginosa [14], Bacillus subtilis [15], Aspergillus tamari, Aspergillus niger, Aspergillus terreus [16] Staphylococcus aureus and Streptomyces [17-19].

The enzyme from Erwinia chrysanthemi and E. coli are predominantly in use as effective drugs for various leukemia diseases [20, 21]. In 2001, the Erwinia chrysanthemi L-asparaginase was FDA-approved and joined the Lasparaginase treatment regimens [22]. Notably, these L-asparaginases harbor an L-glutaminase secondary activity, that is, a capacity to deaminate the amino acid L-glutamine (Gln). Whether this secondary activity has any clinical relevance is still being debated, but it is clear that many of the toxic side effects of L-asparaginase therapy can be ascribed to the L-glutaminase activity [23]. To reduce the L-glutaminase-related toxicity of L-asparaginase therapy, several groups focused on engineering EcA and ErA towards low L-glutaminase variants [24, 25]. Another approach is to search for enzymes that naturally have lower L-glutaminase activity. For successful clinical applications, it is necessary to identify glutaminase-free L-asparaginase, which is obtained from a novel producer organism. In the late 1970s, Distasio reported a "glutaminase-free" L-asparaginase variant from Wolinella succinogenes and Kumar Investigated L-asparaginase in Pectobacterium carotovorum MTCC 1428 with no glutaminase activity [26].

The present study aimed at the isolation of a bacterium from soil samples with low glutaminase activity and investigation of their quantitative production of L-asparaginase, which it might have even more efficient antineoplastic activity.

\section{Materials and Methods}

\subsection{Sample Collection}

Soil samples were collected in the sterilized bags from the depth of $10 \mathrm{~cm}$ from agriculture soils around Gharchak, Tehran, Iran. About 1 gram of soil was added into $10 \mathrm{ml}$ sterile saline solution $(0.9 \% \mathrm{w} / \mathrm{v})$. The suspension is serially diluted from $10-1$ to $10-8$ and $0.1 \mathrm{ml}$ of it was spread onto an agar plate containing $0.1 \%$ L-asparagine as sole nitrogen source, $1 \%$ glucose, and $1.5 \%$ agar in tap water at $\mathrm{pH} 7$ and incubated at $30{ }^{\circ} \mathrm{C}$ for $24-48$ h. Morphologically different colonies were chosen and further purified by repetitive streaking method.

\subsection{Screening Glutaminase Free L-asparaginase}

L-asparaginase producing strains were screened by rapid plate assay method based on their capability to form a pink zone around colonies on agar plates of modified M9 medium. The medium contained: $1 \mathrm{~g}$ glucose, $0.02 \mathrm{~g}$ $\mathrm{MgSO} 4.5 \mathrm{H} 2 \mathrm{O}, 0.001 \mathrm{~g} \mathrm{CaCl} 2.2 \mathrm{H} 2 \mathrm{O}, 0.05 \mathrm{~g} \mathrm{~K} 2 \mathrm{HPO} 4,0.001 \mathrm{~g}$ FeSO4.7H2O, $0.1 \mathrm{~g}$ asparagine and $1.5 \mathrm{~g}$ agar per 100 $\mathrm{ml}$ of Deionized Water. Phenol red at $0.009 \%$ was used as a pH indicator. In the presence of an enzyme, asparagine converted into aspartic acid and ammonia and the color of medium will be changed to pink. The amount of enzyme production is reflected in the diameter of the pink zone. L-glutaminase activity was investigated by replacing asparagine by $0.1 \mathrm{~g}$ of glutamine as a sole nitrogen source.

\subsection{Identification of the Potent L-asparaginase Producing Strain}

The best glutaminase free L-asparaginase producing strain was selected and identification was done based on 16S rDNA sequencing, phylogenetic analysis, and morphological and physiological tests. The sequence deposited in Genbank under accession No. KT361190. Multiple alignments were done with the clustering algorithm with type strains of nearest Staphylococcus species and Salinicoccus roseus as outgroup. A maximum likelihood (ML) phylogenetic tree was drafted with Mega-X software (ver 10.0.5) with the Tamura-Nei method and 100 bootstrap replications.

\subsection{Enzyme Production Medium}

The inoculum was prepared by transferring a loop full of strain MGM1 into $250 \mathrm{ml}$ sterile medium followed by incubation at $30{ }^{\circ} \mathrm{C}$ and $100 \mathrm{rpm}$ for 24 hours. The seeding medium contains: $1 \%$ glucose, $1 \%$ peptone, $0.1 \% \mathrm{~L}-$ asparagine, $0.05 \% \mathrm{~K} 2 \mathrm{HPO} 4 ; 0.02 \% \mathrm{MgSO} 4.7 \mathrm{H} 2 \mathrm{O}, 0.001 \% \mathrm{FeSO} 4.7 \mathrm{H} 2 \mathrm{O}, 0.001 \% \mathrm{CaCl} 2.2 \mathrm{H} 2 \mathrm{O}$ and $100 \mathrm{ml}$ trace elements ( $\mathrm{ZnCl} 2,70 \mathrm{mg}$; MnCl2.4H2O, $100 \mathrm{mg}$; CoCl2.6H2O, $200 \mathrm{mg}$; NiCl2.6H2O, $100 \mathrm{mg}$; CuCl2.2H2O, $20 \mathrm{mg}$; NaMoO4.2H2O, $50 \mathrm{mg}$; Na2SeO3.5H2O, $26 \mathrm{mg}$; NaVO3.H2O, $10 \mathrm{mg}$; and Na2WO4.2H2O, $30 \mathrm{mg}$ in $1000 \mathrm{ml}$ distilled water) in tap water at $\mathrm{pH}$ 7.0. This culture was used to inoculate $2.5 \mathrm{~L}$ of the enzyme-producing medium divided into two $5 \mathrm{~L}$ Erlenmeyer flasks. Flasks were incubated at $30{ }^{\circ} \mathrm{C}$ and $100 \mathrm{rpm}$ for 48 hours. Afterward, the culture media were centrifuged at $10000 \times \mathrm{g}$ for 6 minutes and the supernatant was stored as a crude enzyme. 


\subsection{Enzyme Assay}

L-asparaginase and L-glutaminase assay were calorimetrically determined by measuring the amount of ammonia ion produced from L-asparagine or L-glutamine as substrate by nesslerization method. For assay of enzyme activity, the modified Mashburn and Wriston method was used [27], briefly, $0.5 \mathrm{ml}$ of the crude enzyme was added to assay mixture containing $0.5 \mathrm{ml}$ of $0.04 \mathrm{M} \mathrm{L}$-asparagine and $0.5 \mathrm{ml}$ of $0.1 \mathrm{M}$ Tris-HCl buffer. This mixture was incubated for $2 \mathrm{~h}$ at $37{ }^{\circ} \mathrm{C}$. Then the reaction was stopped by the addition of $0.2 \mathrm{ml}$ of $0.9 \mathrm{M}$ TCA and centrifuged at $13000 \times \mathrm{g}$ for $4 \mathrm{~min}$. One milliliter of supernatant was diluted by $3 \mathrm{ml}$ of distilled water and treated with $0.2 \mathrm{ml}$ of Nessler's reagent. The mixture was incubated at $37{ }^{\circ} \mathrm{C}$ for $15 \mathrm{~min}$, then absorbance determined at $450 \mathrm{~nm}$ and compared with the standard curve which was prepared from ammonium sulfate solution in different concentrations. The one I.U. (International Unit) of L-asparaginase is equal to one mmol of ammonia released from L-asparagine per minute [28].

\subsection{Enzyme Purification}

Purification of the enzyme was performed by a protocol involving ammonium sulfate fractionation and column chromatography on diethylaminoethyl Sephadex (DEAE-Sephadex). Solid ammonium sulfate was added slowly to the culture supernatant with constant stirring to $40 \%$ saturation point and held overnight at $4{ }^{\circ} \mathrm{C}$. The precipitate was pelleted by centrifugation at $10,000 \times \mathrm{g}$ for $10 \mathrm{~min}$ in $4{ }^{\circ} \mathrm{C}$. Finally, the pellet was dissolved in $0.1 \% \mathrm{Tris}-\mathrm{HCl}$ buffer (pH 8) and dialyzed against the same buffer. After dialysis, the tube was kept at $4{ }^{\circ} \mathrm{C}$ for $24 \mathrm{~h}$. The equilibrated enzyme solution was loaded to a DEAE-Sephadex column $(2 \times 5 \mathrm{~cm})$.

The column was equilibrated with $0.1 \%$ Tris- $\mathrm{HCl}$ buffer $(\mathrm{pH} 8)$. After loading of proteins, the column washed with Tris- $\mathrm{HCl}$ buffer for removing of unbound proteins and eluted with one column size of $0.1,0.2,0.3,0.4,0.5$ and $1 \mathrm{M}$ of $\mathrm{NaCl}$ in the same buffer. Thirty fractions were collected and enzyme activity and protein concentration of each was evaluated after dialysis with Nesselerzation and Bradford methods respectively [29].

\subsection{Measurement of Molecular Mass}

The molecular mass of a semi-purified enzyme was estimated by SDS-PAGE gel electrophoresis. The electrophoresis was performed on $10 \%$ of separating gel $(\mathrm{pH} 8.8)$ and $5 \%$ of stacking gel ( $\mathrm{pH}$ 6.8). The protein sample was solubilized in sample buffer by incubation at $95^{\circ} \mathrm{C}$ for $5 \mathrm{~min}$. Then $0.05 \mathrm{ml}$ of this solution was loaded in wells. After electrophoresis, the gel was stained with Coomassie brilliant blue R-250. Wide molecular weight markers (10-250 $\mathrm{kDa}$ ) were used to compare the molecular weight of the purified enzyme.

\subsection{Biochemical Characterization}

\subsubsection{Effect of Temperature and pH on Enzyme Activity}

The effect of different temperatures i.e., $4{ }^{\circ} \mathrm{C}, 25{ }^{\circ} \mathrm{C}, 30{ }^{\circ} \mathrm{C}, 35{ }^{\circ} \mathrm{C}$, and $40{ }^{\circ} \mathrm{C}$ on enzyme activity for three hours was evaluated with the above-mentioned method. For determination of optimum $\mathrm{pH}$, different phosphate buffer with $\mathrm{pH} 4,5,6,7,8,9$ and 10 was used. Buffer systems were sodium dihydrogen phosphate-NaOH (pH 4-8) and disodium hydrogen phosphate- $\mathrm{NaOH}(\mathrm{pH} 9-10)$.

\subsubsection{Effect of Metal Ions and Inhibitors on Enzyme Activity}

The effect of metal ions $\mathrm{Na}^{+}, \mathrm{K}^{+}, \mathrm{Ca}^{2+}, \mathrm{Mg}^{2+}, \mathrm{Fe}^{3+}, \mathrm{Cu}^{2+}, \mathrm{Co}^{2+}, \mathrm{Hg}^{2+}$ and $\mathrm{Zn}^{2+}$ at $5 \mathrm{mM}$ concentration and glucose, urea, glutamine, and EDTA at $1 \mathrm{mM}$ concentration were evaluated after 2 hours' incubation with the purified enzyme at $37^{\circ} \mathrm{C}$ and darkness. The enzyme activities were measured by the previously mentioned method and expressed relative to the observed activity of control [9].

\section{Results}

\subsection{Isolation and Screening of L-asparaginase Producing Bacteria}

Among 75 different strains isolated from agricultural soil samples; 3 strains showed asparaginase activity by changing the color of the modified M9 agar medium from yellow to pink. Between these strains, MGM1 showed the largest pink-colored zone around the colony and therefore was selected for further experiments.

\subsection{Characterization and Identification of Strain MGM1}

DNA extraction and PCR amplification results in a 1500 bp of 16S rDNA. The Ezbiocloud analysis demonstrated $99.13 \%$ similarity to Staphylococcus warneri. Morphological and biochemical properties of the isolated strain were compared with this bacterium and Staphylococcus pasteuri. 
The strain was a cocci-shaped, aerobic, non-oxidative, catalase-positive and, gram-positive bacterium. Summarized results of biochemical and morphological tests were shown in Table 1. Based on the physiochemical properties and the $16 \mathrm{~S}$ rDNA sequence, this bacterium belongs to the Staphylococcus genus and designated as Staphylococcus sp. MGM1. The ML phylogenetic tree (Figure 2) placed MGM1 strain clearly in distinct branch among Staphylococcus genus.
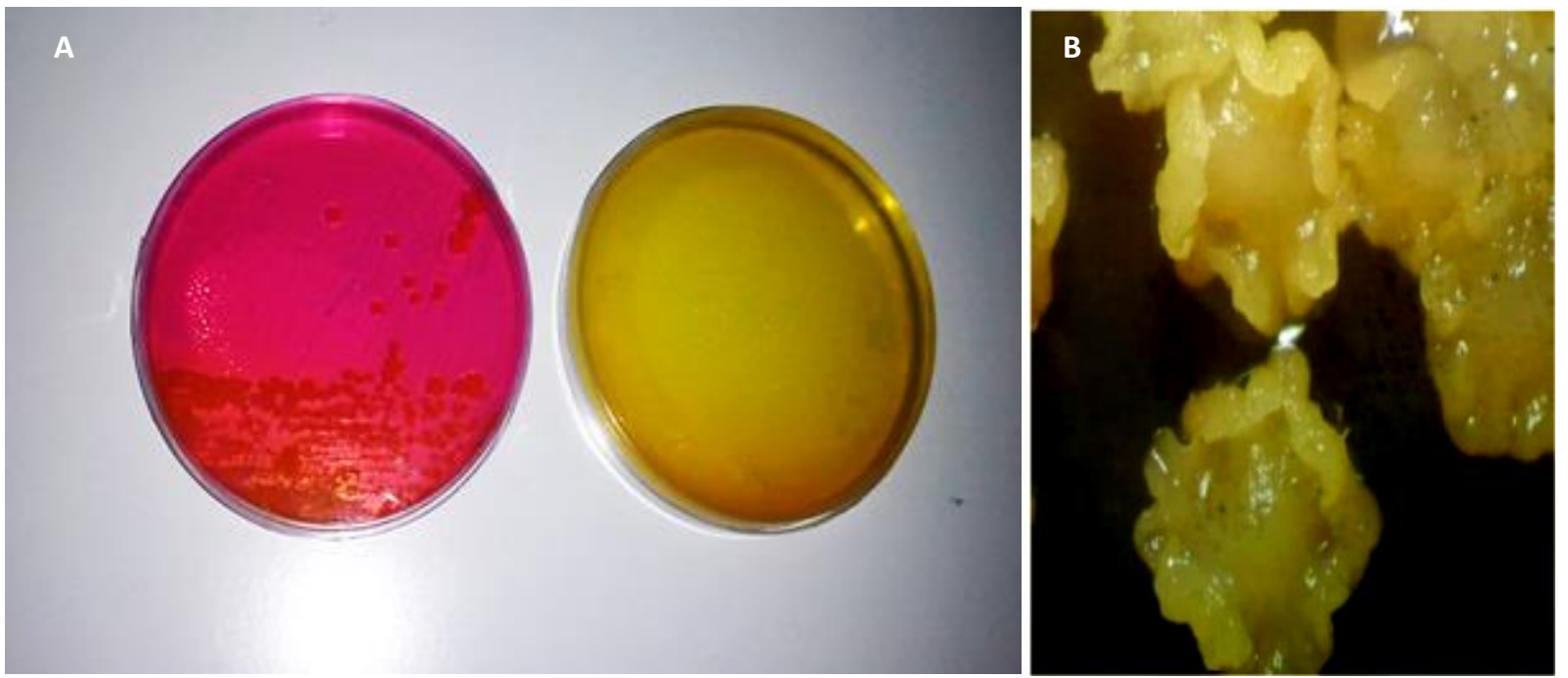

Figure 1. (A): right, M9 medium; left, the color of M9 medium turned to pink after cultured of MGM1; (B): MGM1 colony morphology under a stereomicroscope

Table 1. Some Morphological and Biochemical Characteristics of Strain MGM1

\begin{tabular}{|c|c|c|c|}
\hline Characteristic & $\begin{array}{l}\text { Staphylococcus } \\
\text { pasteuri }\end{array}$ & $\begin{array}{l}\text { Staphylococcus } \\
\text { warneri }\end{array}$ & Strain MGM1 \\
\hline Shape & cocci & Cocci & cocci \\
\hline Gram staining & positive & Positive & positive \\
\hline Motility & - & - & - \\
\hline Catalase & + & + & + \\
\hline Oxidase & - & - & - \\
\hline Anaerobic growth & - & - & + \\
\hline Starch hydrolysis & ND & ND & + \\
\hline Gelatin hydrolysis & - & - & + \\
\hline Nitrate reduction to Nitrite & variable & week & + \\
\hline \multicolumn{4}{|l|}{ Acid production of: } \\
\hline Glucose & + & + & + \\
\hline Glycerol & + & + & - \\
\hline Mannitol & + & + & - \\
\hline sucrose & + & + & + \\
\hline Maltose & + & + & + \\
\hline Lactose & + & + & - \\
\hline Hemolysis & week & week & $\gamma$ \\
\hline Urease & + & + & + \\
\hline Growth in $10-15 \% \mathrm{NaCl}$ & + & + & + \\
\hline Growth at $42^{\circ} \mathrm{C}$ temperature & + & + & + \\
\hline
\end{tabular}




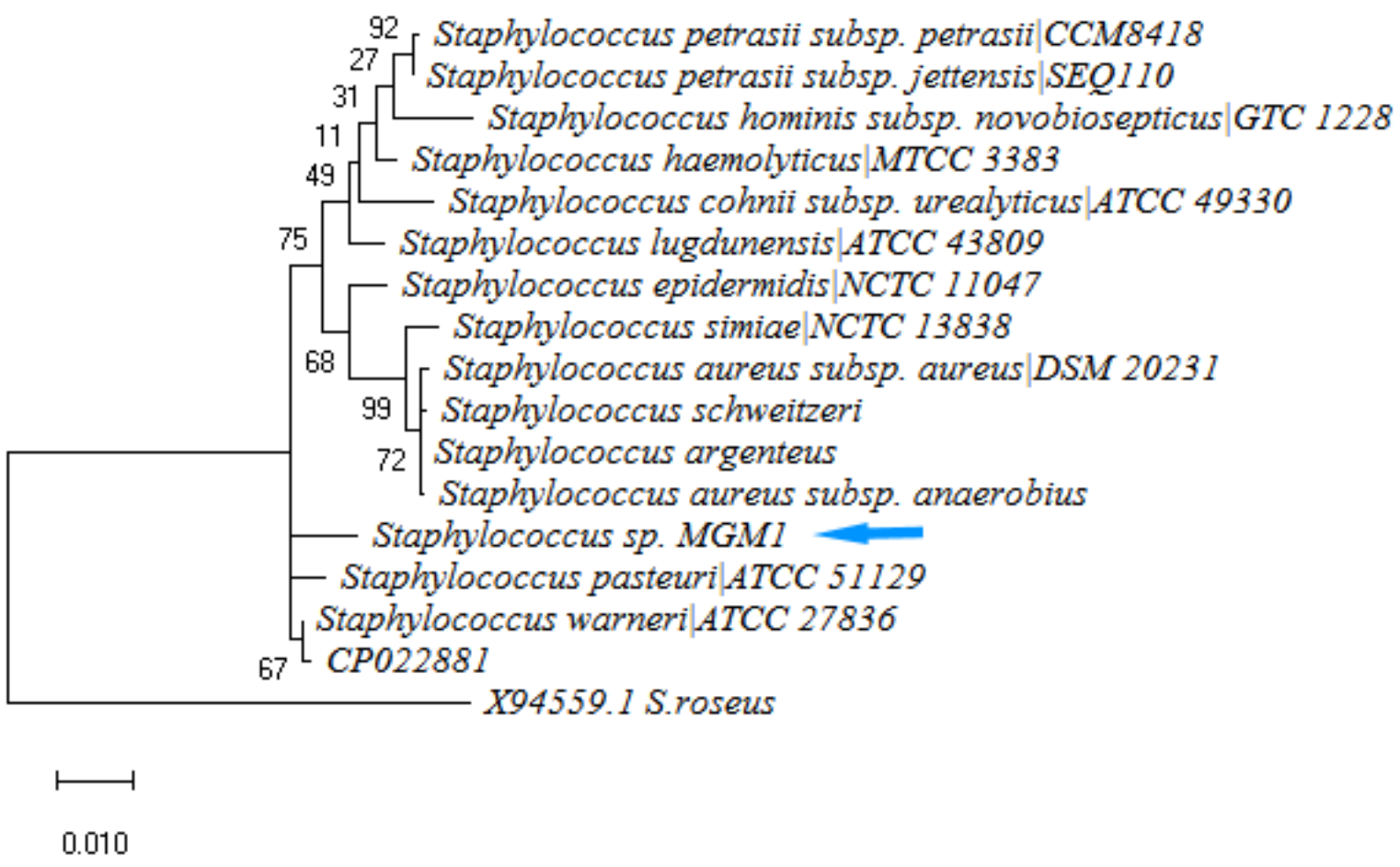

Figure 2. The maximum likelihood phylogenetic relationship of Staphylococcus sp. MGM1 as inferred by Tamura-Nei method with 100 bootstrap

\subsection{Partial Purification of L-asparaginase and Molecular Mass Determination}

The L-asparaginase was purified from the crude enzyme solution through salting out and anion exchange chromatography to a single band on SDS-PAGE. The steps of purification have been presented in Table 2 and Figure 3. The highest concentration of enzyme in centrifuged media was $4.93 \mathrm{IU} / \mathrm{ml}$ with $0.126 \mathrm{IU} / \mathrm{mg}$ specific activity. Ammonium sulfate precipitation recovered $19.47 \%$ of the enzyme, whereas specific activity raised to $0.965 \mathrm{IU} / \mathrm{mg}$. Final purification carried out by DEAE-Sephadex column showed the highest enzyme activity in fraction 3 with 1.63 IU/mg specific activity, which corresponds to 12.93 purification fold. This fraction was used for the SDS-PAGE analysis and showed a single band on gel coincident with a molecular weight of $115 \mathrm{kDa}$ (Figure 4). The electrophoresis of other purification steps reveals the marked improvement in the purification of L-asparaginase using a DEAE-Sephadex column.

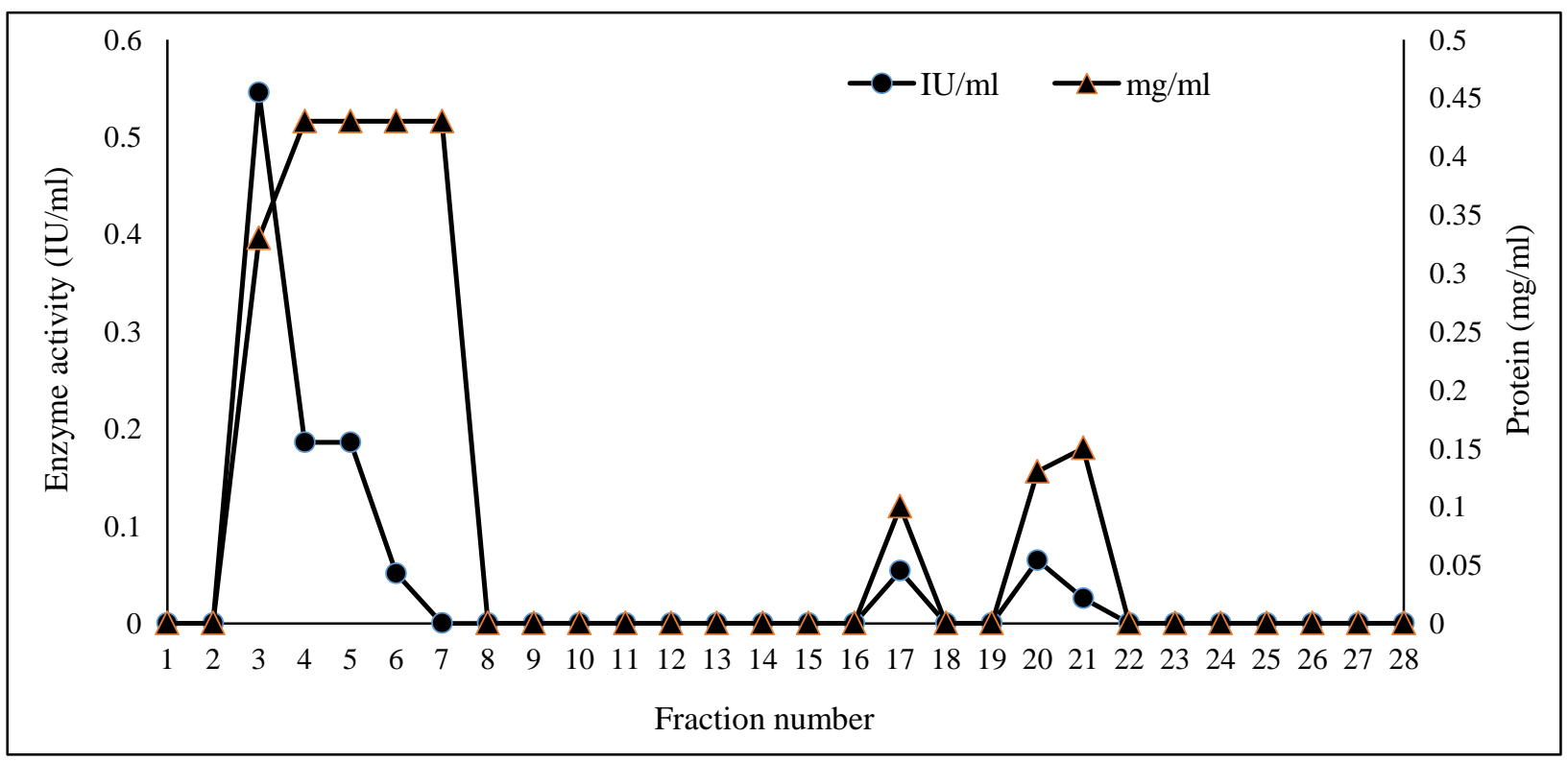

Figure 3. Elution profile of MGM1 L-aspsarainase on DEAE-Sephadex A25; (•) total activity in each fraction; $(\Delta)$ total protein in each fraction 
Table 2. Purification profile of L-asparaginase from Staphylococcus MGM1

\begin{tabular}{cccccc}
\hline Step & Total activity $(\mathbf{I U})$ & Total protein $(\mathbf{m g})$ & Specific activity $(\mathbf{I U} / \mathbf{m g})$ & Purification fold & Yield (\%) \\
\hline Crude extract & 4.93 & 39 & 0.126 & - & 100 \\
$\left(\mathrm{NH}_{4}\right)_{2} \mathrm{SO}_{4}$ precipitation & 0.96 & 1.38 & 0.695 & 5.79 & 19.47 \\
DEAE-Sephadex & 0.54 & 0.33 & 1.63 & 12.93 & 10.95 \\
\hline
\end{tabular}

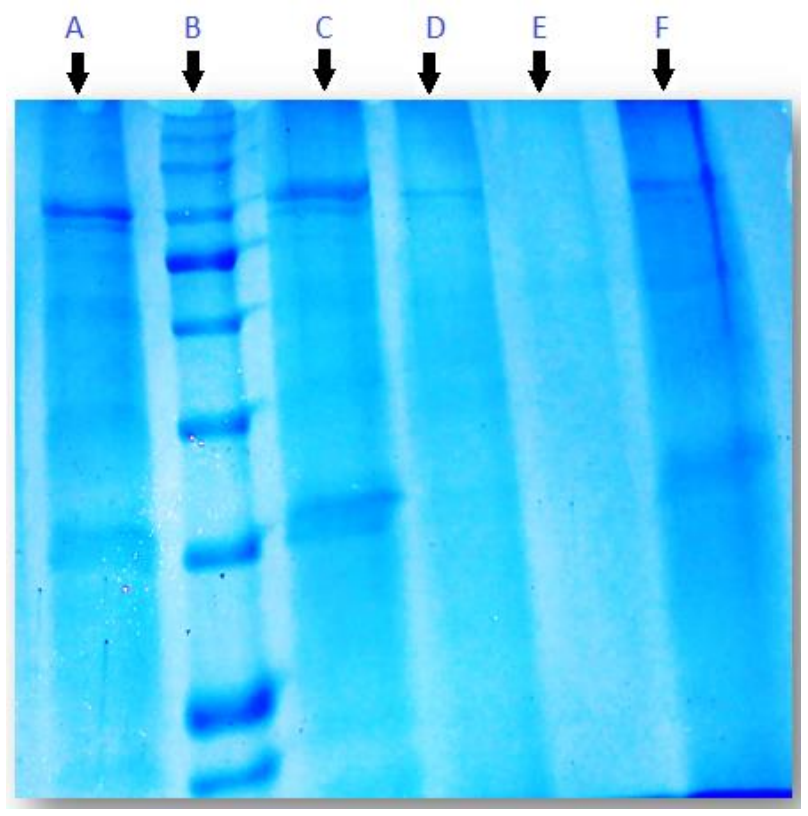

Figure 4. SDS-PAGE of the purified enzyme and the molecular marker. A: supernatant of production culture; B: molecular weight marker; C: ammonium sulfate precipitate after dialysis; and D: fraction 3 of DEAE Sephadex anion exchange column.

\subsection{Effect of Temperature and pH on Enzyme Activity}

The effect of temperature on L-asparaginase activity was measured at $4{ }^{\circ} \mathrm{C}, 25{ }^{\circ} \mathrm{C}, 30{ }^{\circ} \mathrm{C}, 35^{\circ} \mathrm{C}, 40{ }^{\circ} \mathrm{C}$ and $45{ }^{\circ} \mathrm{C}$ in $\mathrm{pH} 7$ by using L-asparagine as substrate. The thermal activity of the crude enzyme was obviously optimal at $35^{\circ} \mathrm{C}$ and the enzyme retained greater than $50 \%$ of the maximum activity from $30{ }^{\circ} \mathrm{C}$ to $37{ }^{\circ} \mathrm{C}$ (Figure 5 ). At $37{ }^{\circ} \mathrm{C}$, it exhibited $60 \%$ of the maximal activity. The effect of different $\mathrm{pH}$ on the enzyme activity was shown in Figure 5 . The highest activity observed at $35^{\circ} \mathrm{C}$ and $\mathrm{pH} 8.0$ and more than $50 \%$ of the maximum activity retained between pH 6.5 and 8.5 (Figure 6).

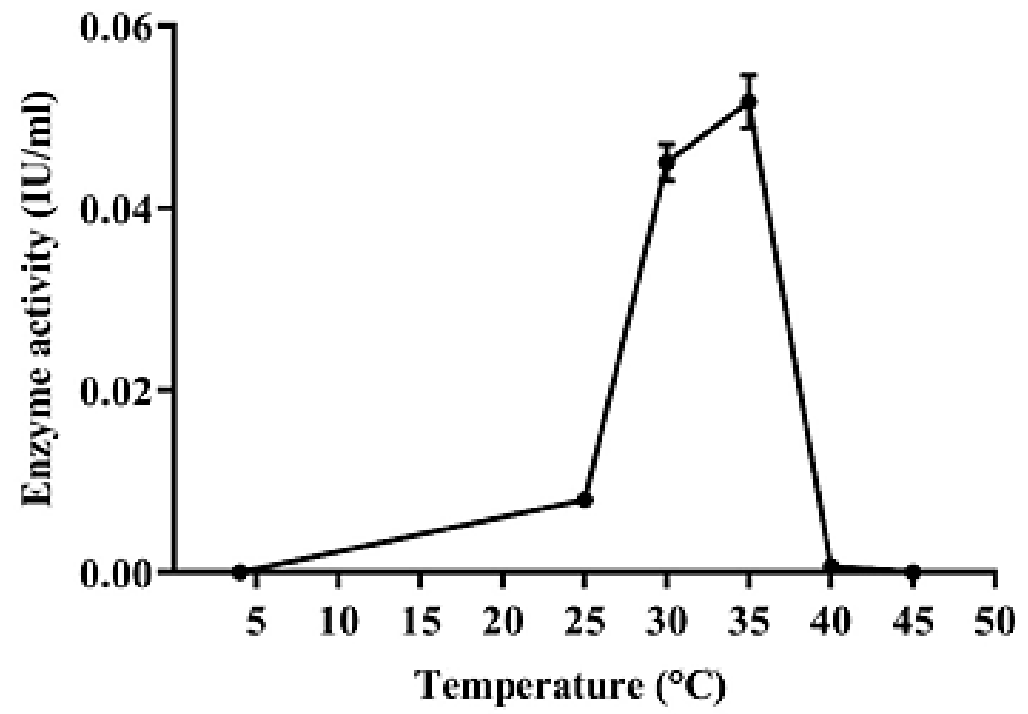

Figure 5. The effect of temperature on enzyme activity and its stability at $4,25,30,35,40$ and $45^{\circ} \mathrm{C}$ for 2 hours 


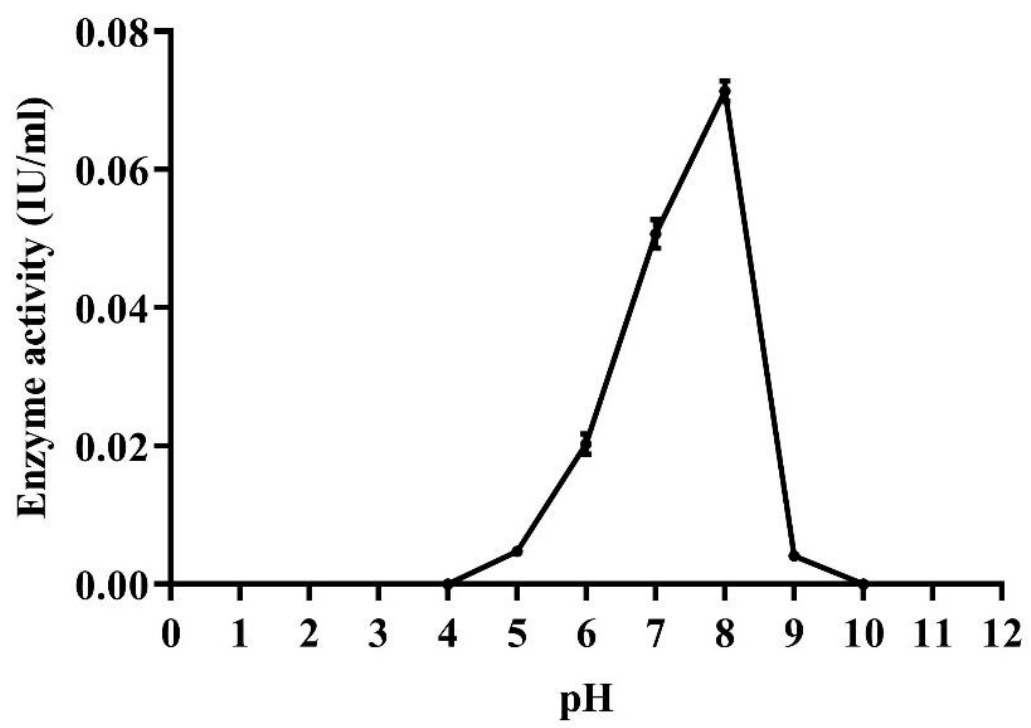

Figure 6. The effect of pH on enzyme activity at $35^{\circ} \mathrm{C}$ and its stability for 2 hours in the range of $4-10$

\subsection{Effect of Metal Ions and Inhibitors on Enzyme Activity}

Figure 7 demonstrates the effect of various metal ions and some of human blood serum components on Lasparaginase activity of Staphylococcus sp. MGM1. Glutamine and $\mathrm{Mg}^{2+}$ had the least effect on the activity of Lasparaginase while $\mathrm{K}^{+}, \mathrm{Fe}^{3+}$, glucose, and $\mathrm{Na}^{+}$enhance its activity by 254, 236, 200, and $136 \%$ respectively. However, urea and EDTA inhibit $45 \%$ of the enzyme activity but $\mathrm{Ca}^{2+}, \mathrm{Cu}^{2+}, \mathrm{Co}^{2+}, \mathrm{Hg}^{2+}$, and $\mathrm{Zn}^{2+}$ are potent inhibitors of the enzyme and reduce its activity by almost $95 \%$.

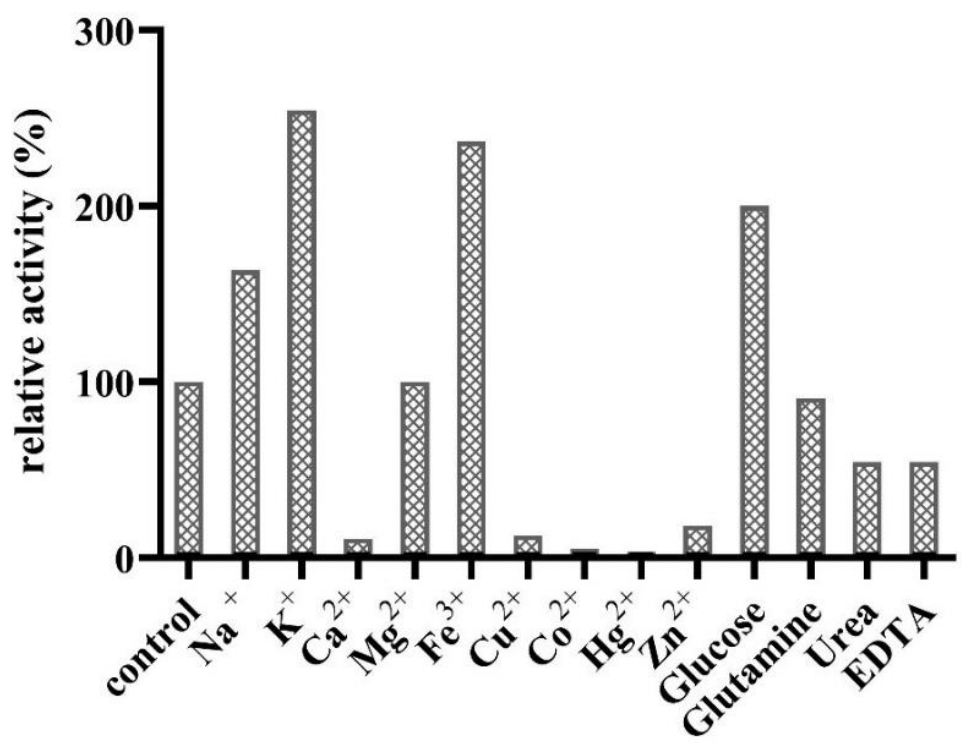

Figure 7. The effect of metal ions at $5 \mathrm{mM}$ and some blood serum components at $1 \mathrm{mM}$ concentration

\section{Discussion and Conclusion}

Recent application of L-asparaginase in the treatment of certain kinds of leukemia such as acute lymphoblastic leukemia made it active research field in cancer therapy. However, like some other drugs, the longtime use of Lasparaginase may cause a side effect because of the glutaminase activity of the enzyme. In this study, we isolated a glutaminase free L-asparaginase producing bacterium from farm soil. According to $16 \mathrm{~S}$ rDNA sequencing and morphological properties, the isolated bacterium was found to belong to the Staphylococcus genus. However, its physiochemical characteristics are considerably different from the nearest hit (S. warneri, 99.13\% homology) therefore; more experiments such as DNA-DNA hybridization should be done for exact identification of the bacterium. L-asparaginase from gram-positive bacteria other than Actinobacteria has been poorly studied and exploration of these species as new sources of L-asparaginases may be worthwhile. Sobis and Mikucki report an Lasparaginase from a Staphylococcus with optimum $\mathrm{pH}$ between 8.6 and 8.9 and optimum temperature around $30{ }^{\circ} \mathrm{C}$ [30]. Staphylococcus sp. - 6A [31] was found to produce $6 \mathrm{IU} / \mathrm{ml}$ L-asparaginase with the highest activity at $39^{\circ} \mathrm{C}$ and pH 7.5 with unknown mass. In 2014, Han et al. [32] isolated NaCl-tolerant Staphylococcus sp. OJ82 from the 
traditional Korean fermented food with the ability to producing $2.3 \mathrm{IU} / \mathrm{ml} \mathrm{L}$-asparaginase which was active in temperatures $37-50{ }^{\circ} \mathrm{C}$ and $\mathrm{pH} 8-10$.

The enzyme was a dimer with $67 \mathrm{kDa}$ molecular mass and subsequently cloned in E. coli and purified by affinity chromatography to $86.9 \mathrm{IU} / \mathrm{mg}$ specific activity and a 98.75 -fold purification. The isolated Staphylococcus of this study produces $4.93 \mathrm{IU} / \mathrm{ml}$ enzyme with the best activity at the temperature of $35{ }^{\circ} \mathrm{C}$ and the $\mathrm{pH}$. These results are consistent with other staphylococcal asparaginases reported elsewhere. The optimal $\mathrm{pH}$ and temperature of enzymes from staphylococci were near the physiological $\mathrm{pH}(7.4)$ and temperature $\left(35-37{ }^{\circ} \mathrm{C}\right)$, thus these L-asparaginases might be suitable for therapeutic applications. Partial purification of L-asparaginase carried out by ammonium sulfate precipitation and DEAE anion-exchange chromatography result in an enzyme with $115 \mathrm{kDa}$ molecular weight and 12.93-fold increase in the specific activity. L- asparginases from other gram positive sources have a very broad range of molecular mass from $45 \mathrm{kDa}$ in Bacillus sp. [33] to $140 \mathrm{kDa}$ in Streptomyces noursei [19].

The monovalent cations exhibit a considerable increase in activity of L-asparaginase. The enzymes from Entrobacter cloacae and Pectobacterium carotovorum also showed the same effect [28, 34]. However, no change in activity was observed in only other study of metal ions effect on staphylococcal asparaginases [32]. The divalent cations except magnesium almost totally inhibit L-asparaginase in this study. Han et al. also have reported inhibition of SoAsn by $\mathrm{Ca}^{2+}$ and $\mathrm{Mg} 2+$ but increased activity by $\mathrm{Co}^{2+}(263.9 \%)$, ferrous ion $(203.7 \%)$ and $\mathrm{Cu}^{2+}(109.3 \%)$. $\mathrm{Ca}^{2+}$, $\mathrm{Zn}^{2+}$ and $\mathrm{Hg}^{2+}$ have been reported as inhibitors of E. cloacae enzyme [34]. Also reported the inhibitory effect of $\mathrm{Hg} 2+$. L-asparaginases from Vibrio species [35, 36] and fungal sources such as Fusarium culmorum [37] and Aspergillus nidulans [38] were effected by $\mathrm{Cu}^{2+}$ from complete inhibition to $84 \%$ decrease in activity. Ferric ion markedly enhance activity of MGM1 asparaginase and inhibition of its half activity by EDTA suggest that Fe3+ is the cofactor of the enzyme. Among blood serum components glucose increase activity by $200 \%$ while glutamine did not show any effect and urea inhibit $45 \%$ of activity [9]. Have reported that $58 \%$ of activity of S. brollosae asparaginase decreased by $1 \mathrm{mM}$ urea.

The glutaminase side activity of enzyme is the cause of several problems associated by glutamine depletion such as reducing the synthesis of important proteins like albumin, fibrinogen, insulin, and protein C. The enzyme reported here was very specific for L-asparagine, with no glutaminase activity in contrast to the E. Coli L-asparaginase and SoAsn from Staphylococcus sp. OJ82, which is associated with $19 \%$ and $58.2 \%$ relative glutaminase activity, respectively [32]. The present study clearly supports usefulness of simple soil screening techniques. The isolated Lasparaginase is highly active in physiological $\mathrm{pH}$ and temperature and easily purified in two steps. In addition, the enzyme is greatly enhanced in the presence of usual ions and other ingredients of human blood serum that makes it a potential candidate for enzyme therapy of leukemia.

Among the drugs used to treat leukemia, Asparaginase is one of the best drugs that can be used in the treatment of various types of leukemia like ALL. Nowadays, among the different enzyme-producing sources, only 2 of them "the enzyme extracted by Erwinia and E. coli" are used. However, it is ongoing to find new sources of producer Enzymes with more distinct and consistent features with the body. According to the obtained results in this study, like the stability of the asparaginase enzyme isolated from MGM1 sp in body physiological conditions such as temperature $35 \mathrm{C}, \mathrm{pH} 8$, and various ions and compounds, as well as the absence of glutaminase activity, can be hoped that the producing enzyme, is an enzyme with good therapeutic properties and low side effects requiring clinical trials and Application to laboratory models and cancer cell lines. On the other hand, considering the results of this study and the enzymatic activity of the bacterium compared to similar studies, it can be said that the enzyme L-asparaginase produced by MGM1, is an isoenzyme with different characteristic properties, as well as it seems to be a new strain of Staphylococcus that needs further studies for its accurate identification. It is important in this respect that accurate identification of the source of the enzyme producer contributes greatly to the research and analysis of the enzyme produced by the bacterium.

\section{Funding}

This article is part of the master thesis of Shahid Beheshti University, Partial support was provided by Faculty of Life Sciences and Biotechnology of Shahid Beheshti University.

\section{Acknowledgements}

Authors are thankful of the Faculty of Biological Sciences and Technologies of Shahid Beheshti University.

\section{Declaration of Competing Interest}

The authors declare that they have no known competing financial interests or personal relationships that could have appeared to influence the work reported in this paper. 


\section{Ethical Approval}

All procedures performed in studies involving human participants were in accordance with the ethical standards of the Shahid Beheshti University affiliated to Iran's Ministry of Science, Research \& Technology and with the 1964 Helsinki declaration and its later amendments or comparable ethical standards.

\section{References}

[1] Athale, U. H., \& Chan, A. K. (2003). Thrombosis in children with acute lymphoblastic leukemia. Thrombosis Research, 111(3), 125-131. doi: 10.1016/j.thromres.2003.10.013.

[2] Satheesan Kavya, P. (2019). Isolation and Characterization of L- Asparaginase Producing Endophytic Bacteria from Simarouba Gluaca; International Journal of Animal Science and Technology, 3(1), 1. doi:10.11648/j.ijast.20190301.11.

[3] Ashok, A., Doriya, K., Rao, J. V., Qureshi, A., Tiwari, A. K., \& Kumar, D. S. (2019). Microbes Producing L-Asparaginase free of Glutaminase and Urease isolated from Extreme Locations of Antarctic Soil and Moss. Scientific Reports, 9(1). doi:10.1038/s41598-018-38094-1.

[4] Mishra, A. (2006). Production of L-Asparaginase, an Anticancer Agent, From Aspergillus niger Using Agricultural Waste in Solid State Fermentation. Applied Biochemistry and Biotechnology, 135(1), 33-42. doi:10.1385/abab:135:1:33.

[5] Narta, U. K., Kanwar, S. S., \& Azmi, W. (2007). Pharmacological and clinical evaluation of l-asparaginase in the treatment of leukemia. Critical Reviews in Oncology/Hematology, 61(3), 208-221. doi: 10.1016/j.critrevonc.2006.07.009.

[6] Rosén, J., \& Hellenäs, K.-E. (2002). Analysis of acrylamide in cooked foods by liquid chromatography tandem mass spectrometry. The Analyst, 127(7), 880-882. doi:10.1039/b204938d.

[7] Morales-Gonzalez, M., Martinez, B. S., Ramirez-Rodriguez, L., Gómez, J., \& Diaz, L. (2019). Optimization of L-asparaginase activity of Actinobacteria isolated from Guaviare river sediments in Colombia. Tropical Journal of Pharmaceutical Research, 17(11), 2199. doi:10.4314/tjpr. v17i11.13.

[8] Teodor, E., Litescu, S.-C., Lazar, V., \& Somoghi, R. (2009). Hydrogel-magnetic nanoparticles with immobilized l-asparaginase for biomedical applications. Journal of Materials Science: Materials in Medicine, 20(6), 1307-1314. doi:10.1007/s10856-008$3684-\mathrm{y}$.

[9] El-Naggar, N. E.-A., Deraz, S. F., El-Ewasy, S. M., \& Suddek, G. M. (2018). Purification, characterization and immunogenicity assessment of glutaminase free L-asparaginase from Streptomyces brollosae NEAE-115. BMC Pharmacology and Toxicology, 19(1). doi:10.1186/s40360-018-0242-1.

[10] Aung, H.-P., Bocola, M., Schleper, S., \& Röhm, K.-H. (2000). Dynamics of a mobile loop at the active site of Escherichia coli asparaginase. Biochimica et Biophysica Acta (BBA) - Protein Structure and Molecular Enzymology, 1481(2), 349-359. doi:10.1016/s0167-4838(00)00179-5.

[11] Kamble, V. P., Rao, R. S., \& Borkar, P. S. (2006). Purification of L-asparaginase from a bacteria Erwinia carotovora and effect of a dihydropyrimidine derivative on some of its kinetic parameters. Indian Journal of Biochemistry and Biophysics (IJBB), 43(6), 391-394. doi:10.1155/2015/309214.

[12] Mukherjee, J., Joeris, K., Riechel, P., \& Scheper, T. (1999). A simple method for the isolation and purification oflasparaginase fromEnterobacter aerogenes. Folia Microbiologica, 44(1), 15-18. doi:10.1007/bf02816214.

[13] Mesas, J. M., Gil, J. A., \& Martin, J. F. (1990). Characterization and Partial Purification of L-Asparaginase from Corynebacterium Glutamicum. Journal of General Microbiology, 136(3), 515-519. doi:10.1099/00221287-136-3-515.

[14] El-Bessoumy, A. A., Sarhan, M., \& Mansour, J. (2004). Production, Isolation, and Purification of L-Asparaginase from Pseudomonas Aeruginosa 50071 Using Solid-state Fermentation. BMB Reports, 37(4), $387-393$. doi:10.5483/bmbrep.2004.37.4.387.

[15] Pradhan, B., Dash, S. K., \& Sahoo, S. (2013). Screening and characterization of extracelluar L-asparaginase producing Bacillus subtilis strain hswx88, isolated from Taptapani hotspring of Odisha, India. Asian Pacific Journal of Tropical Biomedicine, 3(12), 936-941. doi:10.1016/s2221-1691(13)60182-3.

[16] Gurunathan, B., \& Sahadevan, R. (2011). Design of experiments and artificial neural network linked genetic algorithm for modeling and optimization of L-asparaginase production by Aspergillus terreus MTCC 1782. Biotechnology and Bioprocess Engineering, 16(1), 50-58. doi:10.1007/s12257-010-0119-7.

[17] Dharmaraj, S., Ashokkumar, B., \& Dhevendaran, K. (2010). Isolation of marine Streptomyces and the evaluation of its bioactive potential. African Journal of Microbiology Research, 4(4), 240-248.

[18] Dharmaraj, S., \& Sumantha, A. (2009). Bioactive potential of Streptomyces associated with marine sponges. World Journal of Microbiology and Biotechnology, 25(11), 1971-1979. doi:10.1007/s11274-009-0096-1. 
[19] Dharmaraj, S. (2011). Study of L-asparaginase production by Streptomyces noursei MTCC 10469, isolated from marine sponge Callyspongia diffusa. Iranian journal of biotechnology, 9(2), 102-108.

[20] Egler, R., Ahuja, S., \& Matloub, Y. (2016). L-asparaginase in the treatment of patients with acute lymphoblastic leukemia. Journal of Pharmacology and Pharmacotherapeutics, 7(2), 62. doi:10.4103/0976-500x.184769.

[21] Verma, N., Kumar, K., Kaur, G., \& Anand, S. (2007). E. coliK-12 Asparaginase-Based Asparagine Biosensor for Leukemia. Artificial Cells, Blood Substitutes, and Biotechnology, 35(4), 449-456. doi:10.1080/10731190701460358.

[22] Aghaiypour, K., Wlodawer, A., \& Lubkowski, J. (2001). Structural basis for the activity and substrate specificity of Erwinia chrysanthemi L-asparaginase. Biochemistry, 40(19), 5655-5664. doi: 10.1021/bi0029595.

[23] Fisher, S. H., \& Wray, L. V. (2002). Bacillus subtilis 168 Contains Two Differentially Regulated Genes Encoding 1Asparaginase. Journal of Bacteriology, 184(8), 2148-2154. doi:10.1128/jb.184.8.2148-2154.2002.

[24] Nguyen, H. A., Su, Y., Zhang, J. Y., Antanasijevic, A., Caffrey, M., Schalk, A. M., ... Lavie, A. (2018). A Novel 1Asparaginase with low 1-Glutaminase Coactivity Is Highly Efficacious against Both T- and B-cell Acute Lymphoblastic LeukemiasIn Vivo. Cancer Research, 78(6), 1549-1560. doi: 10.1158/0008-5472.can-17-2106.

[25] Gervais, D., O’Donnell, J., Sung, M., \& Smith, S. (2013). Control of process-induced asparaginyl deamidation during manufacture of Erwinia chrysanthemi 1-asparaginase. Process Biochemistry, 48(9), 1311-1316. doi: 10.1016/j.procbio.2013.06.024.

[26] Kumar, S., Dasu, V. V., \& Pakshirajan, K. (2010). Localization and production of novel 1-asparaginase from Pectobacterium carotovorum MTCC 1428. Process Biochemistry, 45(2), 223-229. doi: 10.1016/j.procbio.2009.09.011.

[27] Mashburn, L. T., \& Wriston, J. C. (1964). Tumor inhibitory effect of 1-asparaginase from Escherichia coli. Archives of Biochemistry and Biophysics, 105(2), 450-453. doi:10.1016/0003-9861(64)90032-3.

[28] Husain, I., Sharma, A., Kumar, S., \& Malik, F. (2016). Purification and Characterization of Glutaminase Free Asparaginase from Enterobacter cloacae: In-Vitro Evaluation of Cytotoxic Potential against Human Myeloid Leukemia HL-60 Cells. PLOS ONE, 11(2), e0148877. doi: 10.1371/journal.pone.0148877.

[29] Bradford, M. M. (1976). A rapid and sensitive method for the quantitation of microgram quantities of protein utilizing the principle of protein-dye binding. Analytical biochemistry, 72(1-2), 248-254. doi: 10.1016/0003-2697(76)90527-3.

[30] Moorthy, V., Ramalingam, A., Sumantha, A., \& Shankaranaya, R. T. (2010). Production, purification and characterisation of extracellular L-asparaginase from a soil isolate of Bacillus sp. Afr J Microbiol Res, 4(18), 1862-1867.

[31] Kumar, S., Venkata Dasu, V., \& Pakshirajan, K. (2011). Purification and characterization of glutaminase-free 1-asparaginase from Pectobacterium carotovorum MTCC 1428. Bioresource Technology, 102(2), 2077-2082. doi: 10.1016/j.biortech.2010.07.114.

[32] Han, S., Jung, J., \& Park, W. (2014). Biochemical Characterization of L-Asparaginase in NaCl-Tolerant Staphylococcus sp. OJ82 Isolated from Fermented Seafood. Journal of Microbiology and Biotechnology, 24(8), 1096-1104. doi:10.4014/jmb.1405.05021.

[33] Radha, R., Arumugam, N., \& Gummadi, S. N. (2018). Glutaminase free 1-asparaginase from Vibrio cholerae: Heterologous expression, purification and biochemical characterization. International Journal of Biological Macromolecules, 111, $129-138$. doi: 10.1016/j.ijbiomac.2017.12.165.

[34] Distasio, J. A., Niederman, R. A., Kafkewitz, D., \& Goodman, D. (1976). Purification and characterization of L-asparaginase with anti-lymphoma activity from Vibrio succinogenes. Journal of Biological Chemistry, 251(22), 6929-6933.

[35] Meghavarnam, A. K., \& Janakiraman, S. (2015). Purification and characterization of therapeutic enzyme L-asparaginase from a tropical soil fungal isolate Fusarium culmorum ASP-87. J Anesth Crit Care Open Access, 2(5), 00064. doi: 10.15406/mojpb.2015.02.00064.

[36] Amena, S., Vishalakshi, N., Prabhakar, M., Dayanand, A., \& Lingappa, K. (2010). Production, purification and characterization of L-asparaginase from Streptomyces gulbargensis. Brazilian Journal of Microbiology, 41(1), $173-178$. doi:10.1590/s1517-83822010000100025.

[37] Duval, M., Suciu, S., Ferster, A., Rialland, X., Nelken, B., Lutz, P., ... \& Otten, J. (2002). Comparison of Escherichia coliasparaginase with Erwinia-asparaginase in the treatment of childhood lymphoid malignancies: results of a randomized European Organisation for Research and Treatment of Cancer - Children's Leukemia Group phase 3 trial. Blood, The Journal of the American Society of Hematology, 99(8), 2734-2739. doi: 10.1182/blood. V99.8.2734.

[38] Amena, S., Vishalakshi, N., Prabhakar, M., Dayanand, A., \& Lingappa, K. (2010). Production, purification and characterization of L-asparaginase from Streptomyces gulbargensis. Brazilian journal of Microbiology, 41(1), 173-178. doi: $10.1590 / \mathrm{S} 1517-83822010000100025$. 